\title{
5 The development of the Latin American film industry between 2017 and 2018
}

\author{
Zhengshan Liu
}

\section{The general development of the Latin American film industry}

Latin America is composed of 34 countries and regions with a total population of 645 million. In 2017, the regional economic growth was 1.3 percent, which is lower than the world average. The development of the film industry is closely related to the development of the regional economy. Since 2014, the box office growth rate in Latin America has risen and then fallen, but the fluctuation is not significant (Figure 5.1).

Based on the regional box office gross (Figure 5.2), though the total population of Latin America is much higher than that of the United States or Canada, the gross domestic product (GDP) and the box office do not total even one-third of the box office of the United States or Canada. Globally, the box office of Latin America accounts for 8.4 percent of the global box office in 2017, while its residents accounted for about 9.3 percent of the global population.

Based on Figure 5.3, although the box office growth in Latin America has a downward trend (compared with Figure 5.1, some years are negative growth), the overall number of screens is increasing.

\section{The development of the film industry in four Latin American countries}

This chapter takes four major Latin American countries as examples: Mexico, Argentina, Brazil and Colombia.

\section{Analysis of the Mexican film industry}

Mexico borders on the United States, with a population of about 120 million, ranking 11th in the world in terms of economic strength. It is the region with the fastest economic development in Latin America and is about to become one of the emerging "Tiger Economies." In the mid-twentieth century, Mexican films had its golden age in its history of film, and a number of internationally influential films emerged, including the movie Yesenia, which 


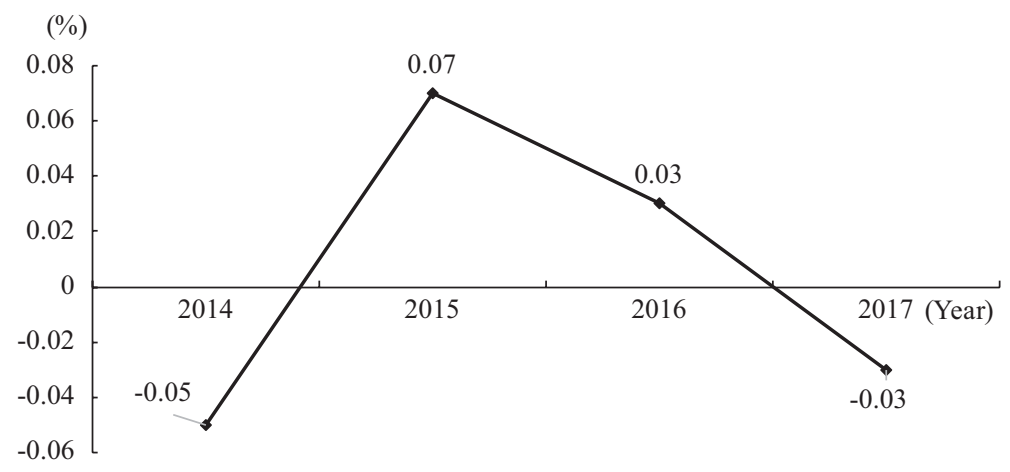

Figure 5.1 Box office growth rate of Latin America, 2014-2017.

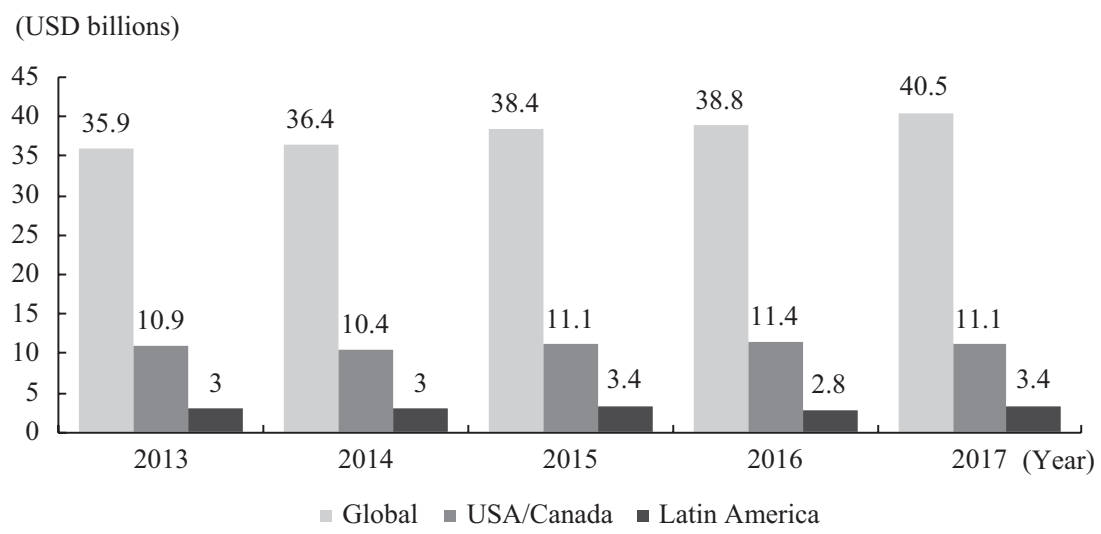

Figure 5.2 Comparison of box office in Latin America, North America and the world, 2013-2017.

is a household name in China. However, since the 1960s, due to the economic crisis, many Mexican film companies have gone bankrupt and have closed down, and the Mexican film industry entered a stage of decline. Since the 1990s, with the improvement of the economic situation, the government has paid more attention to the film industry, and introduced a series of policies to promote film development, such as the film promotion plan, a corporate 10 percent tax rate, and a high-quality film production fund (FOPROCINE), and the Film Investment and Incentive Fund (FIDECINE) to promote the production of movies. In terms of film industry infrastructure construction, Mexico's development rate is quite impressive. As shown in Figure 5.4, since 


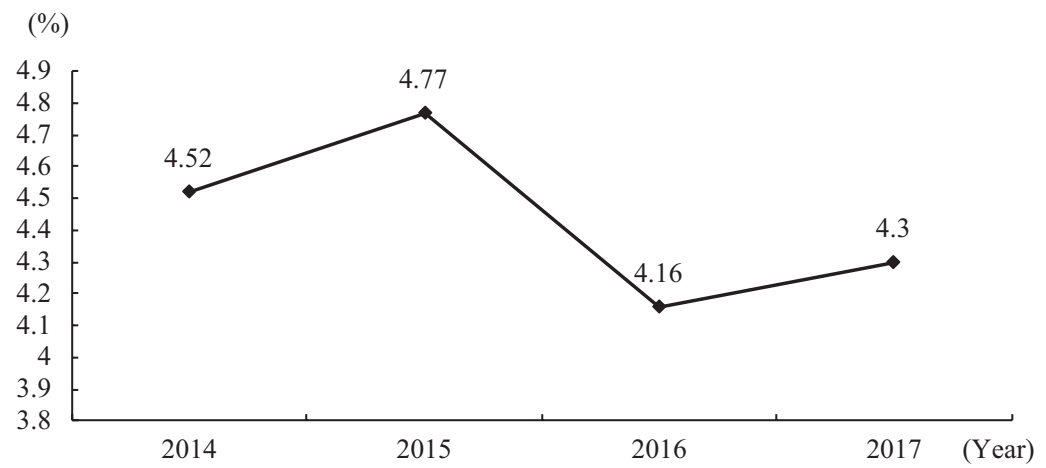

Figure 5.3 Screen growth rate in Latin America, 2014-2017.

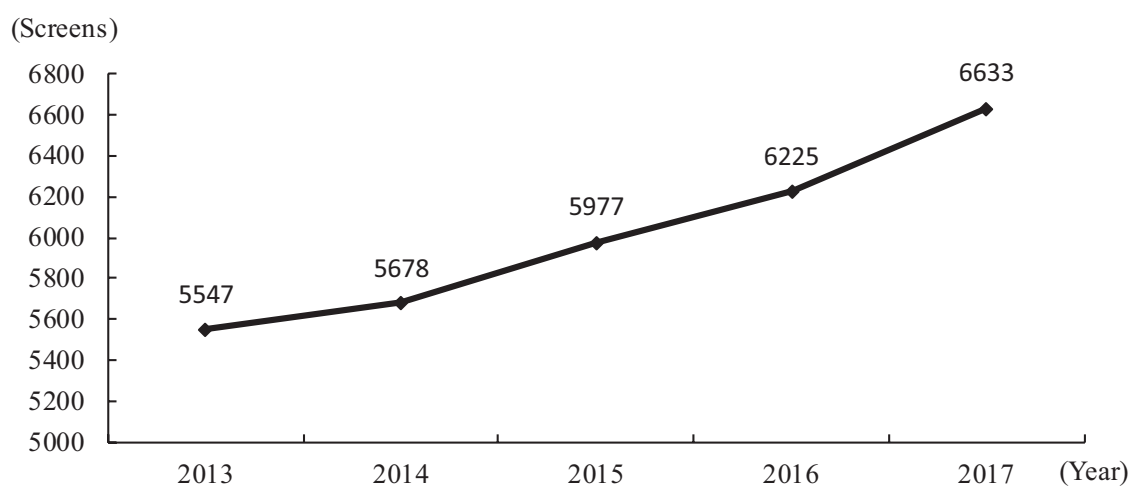

Figure 5.4 Number of screens in Mexico, 2013-2017.

2013, the number of screens in Mexico has continued to rise, from 5,547 in 2013 to 6,633 in 2017, and the per capita level is comparable to that of China.

With the development of the economy and the improvement in the cinema infrastructure, the number of moviegoers in Mexico has continued to rise, though the growth rate is not as fast as that of the screen numbers (Figure 5.5). This shows that Mexico has a film market with sustained development and good prospects. However, box office growth in Mexico fluctuated slightly in 2018: 433 films were released in Mexico, down from 453 in 2017. In 2018, the movie box office reached 15.719 billion pesos, which was lower than 2017 .

Based on Figure 5.6, the market competitiveness of Mexican domestic films is not strong, and the market share of domestically produced films is basically less than 12 percent. 


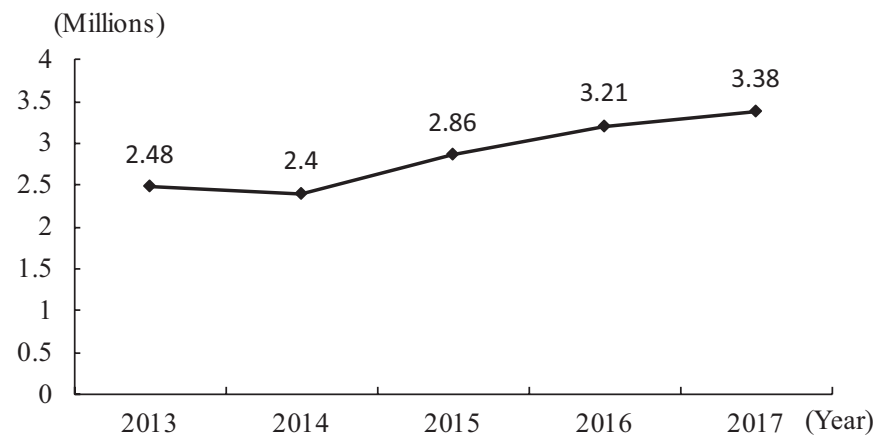

Figure 5.5 Cinema attendance in Mexico, 2013-2017.

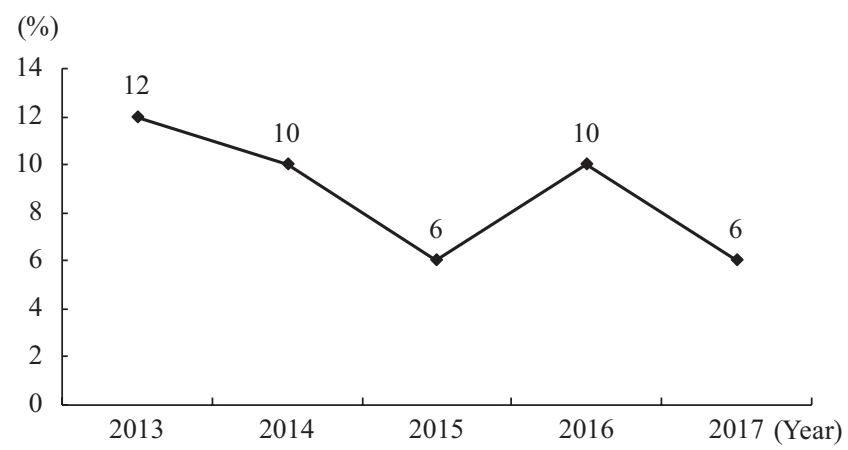

Figure 5.6 Market share of domestic films in Mexico, 2013-2017.

Judging from the results of Box Office Mojo and Internet Movie Database, the top ten box office movies in Mexico for 2018 are Avengers: Infinity War, The Incredibles 2, Jurassic World: Fallen Kingdom, Aquaman, Black Panther, Hotel Transylvania 3: Summer Vacation, Overboard, Venom, The Nun, and Deadpool 2. All these films are foreign language movies, mostly Hollywood movies.

Of the 433 movies released in 2018, there are 101 domestic movies. Comedy movies are the most popular genre in the top ten list of domestic movie box office, with the comedy Ya Veremos topping the list. Compared with its poor market share, the influence of Mexican movies is extraordinary. Gravity (2014), Birdman (2015), The Revenant (2016) and The Shape of Water (2017) are all directed by filmmakers of Mexican origin, who are all Oscar winners. In 2018, the global film critics' most popular film was Roma, directed by Mexican filmmaker Alfonso Cuarón. The New York Times article "The Best Film of 2018" 
lists Roma in first place. The film won the Golden Lion Award at the 75th Venice International Film Festival, as well as the 91st Academy Awards for Best Director, Best Cinematography and Best Foreign Language Film.

\section{Analysis of the Argentinian film industry}

The film industry in Argentina has experienced ups and downs, but in the twenty-first century it has entered a stable development path. In 2009, the film The Secret in Their Eyes, directed by the Argentinian director Juan José Campanella, won the Academy Award for Best Foreign Language Film. In the top ten list of the American Film Review magazine in 2018, the Argentinian female director, Lucrecia Martel's Zama topped the list. Founded in 1989, the Mar del Plata International Film Festival in Argentina is the only competitive international film festival in Latin America recognized by the Fédération Internationale des Associations des Producteurs de Film (FIAPF).

At the government level, Argentina attaches great importance to the film industry and introduced the Law on Domestic Film Industry Promotion. The National Institute of Cinema and Audiovisual Arts (INCAA), a specialized film authority, has incorporated film into the national industrial framework since 2003 and set up a "film production fund" to fund new movies. The amount of funding is based on the quality of the film. The fund also subsidizes new talents in film industry. At the same time, the bureau also has signed agreements with some of the largest banks in Argentina to offer more favorable interest rates for cinema facilities and technology upgrades, which promoted the improvement of the film infrastructure. The bureau not only cooperates with some universities to train film talent, but has also set up a special film school, and provides education and training for free. Theaters are also set up to support independent filmmakers with the opportunity to screen their films. These policies have driven the development of the film industry in Argentina. From the perspective of the film industry infrastructure construction, the number of screens in Argentina continued to grow, from 866 in 2013 to 963 in 2017.Although the growth rate of screens has declined in 2017, the growth has still been maintained overall (Figure 5.7).

Argentina's 2015 cinema attendance exceeded its previous record. However, since 2015, the numbers of moviegoers in Argentina have been declining (Figure 5.8). Compared to the past, the cinema attendance has remained high in recent years. In 2010, the number of viewers in Argentina was 38 million. In 2017, although it was down from the highest point of 50 million in 2015, there were still 47 million, far higher than that in 2010 .

Theoretically, there is a strong correlation between cinema attendance and box office. A higher attendance often means a higher box office. With the decrease of the growth rate of attendance, the total box office growth rate in Argentina also showed a downward trend, but the two are not in synchronization. In 2015, the cinema attendance was at the highest level in recent years, and then it continued to decline. However, the box office growth rate lagged 


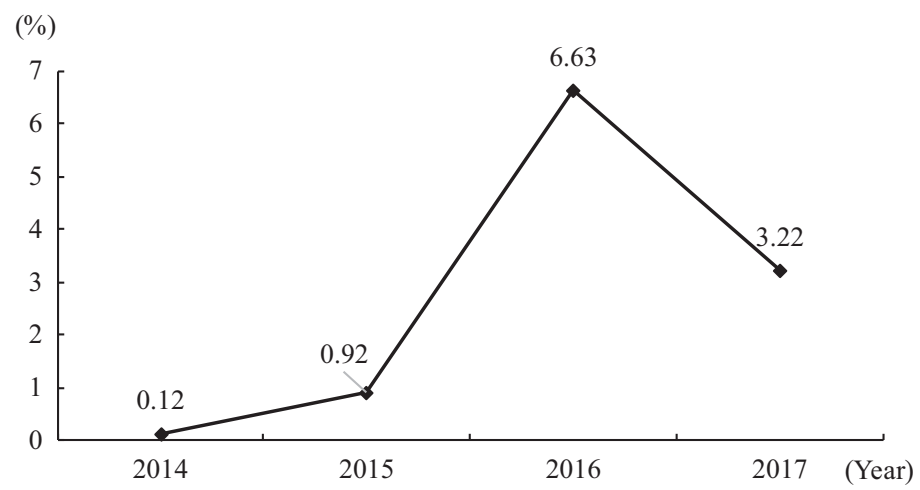

Figure 5.7 Growth rate of Argentina's screen numbers, 2014-2017.

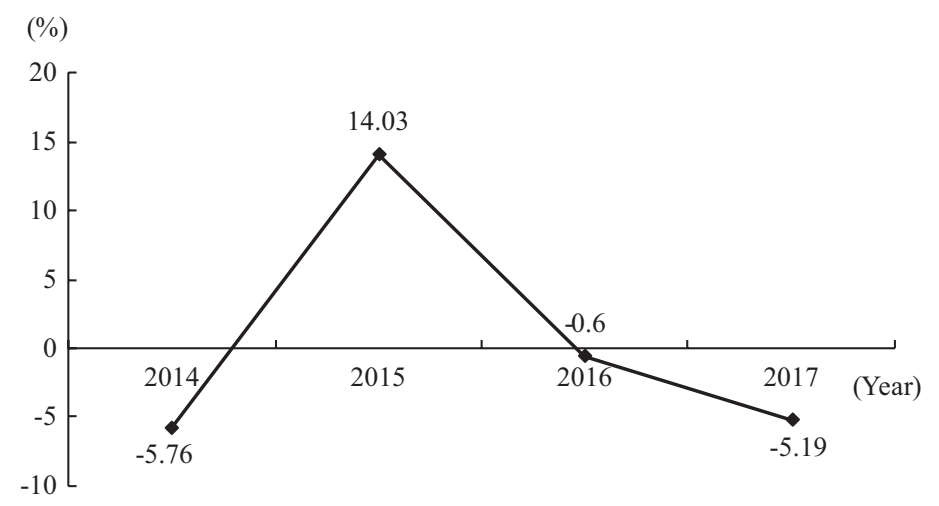

Figure 5.8 Growth rate of Argentina's movie attendance, 2014-2017.

behind for one year, reaching its peak in recent years in 2016 (Figure 5.9). The reason behind this may be related to the law of demand.

Comparing Figure 5.10 and Figure 5.9 shows that the growth rate of the average ticket price is consistent with that of the box office. Calculating the correlation coefficient between the two, the value is found to be as high as 0.94, which is obviously inconsistent with economic theory. According to the law of demand, price has a reverse relationship with demand, and the rise in entry fees has mostly led to a decline in the total box office. The case of Argentina seems to indicate that the rise and fall of the total box office are related to the rise and fall of movie entrance fees. Due to the lack of relevant data, the mechanism is still unknown, and the reasons behind this need to be studied further. 


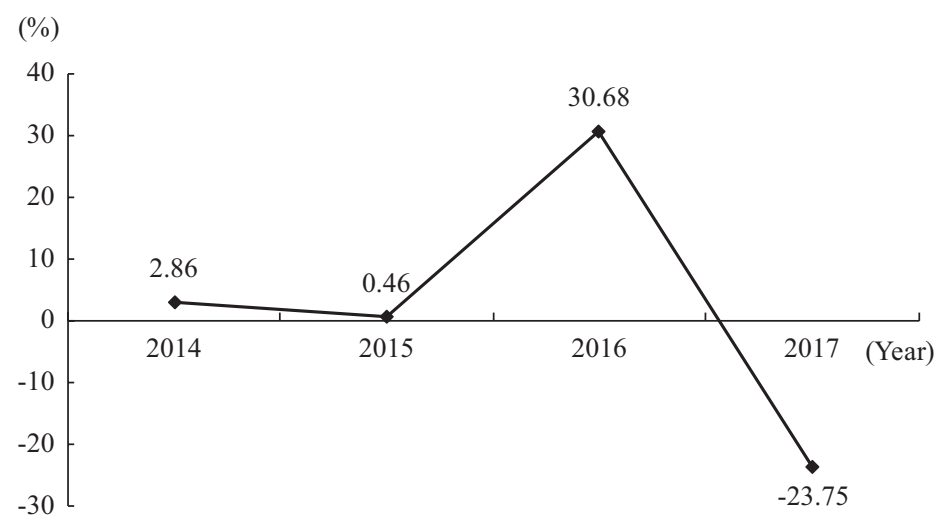

Figure 5.9 Growth rate of the Argentine box office, 2014-2017.

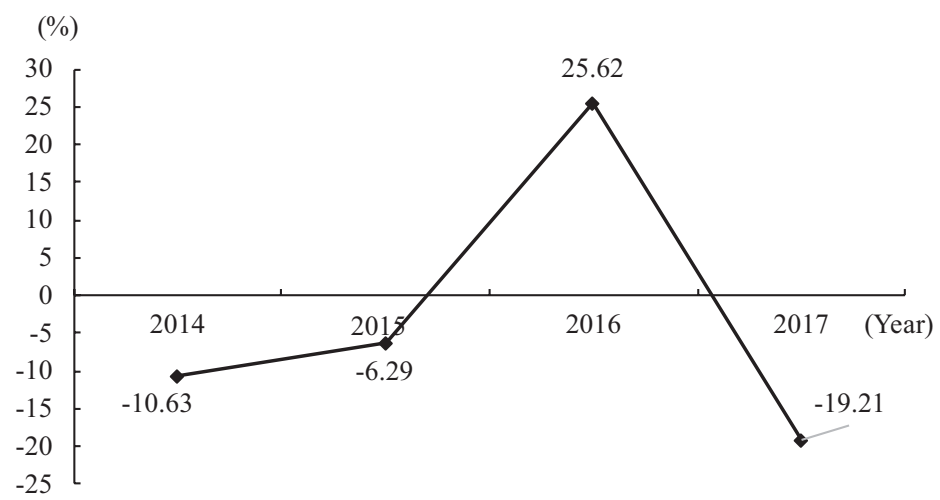

Figure 5.10 Average ticket price growth rate in Argentina, 2014-2017.

Like other Latin American countries, Argentina is also deeply influenced by neoliberalism and has adopted a policy of full openness to the film market, which led to the expansion of Hollywood films. In 2014, the domestic box office share was only 4.74 percent. In recent years, due to the effectiveness of the government's various film support policies, the box office performance of local films has become increasingly prominent. The best result is that of 2016, when the proportion of domestic movie box office jumped to 7.80 percent (Figure 5.11).

However, in general, the Argentine film market is still subject to Hollywood's dominance. For example, in 2018, the top ten box office movies in Argentina were Avengers: Infinity War, The Incredibles 2, Coco, Hotel Transylvania 3: 


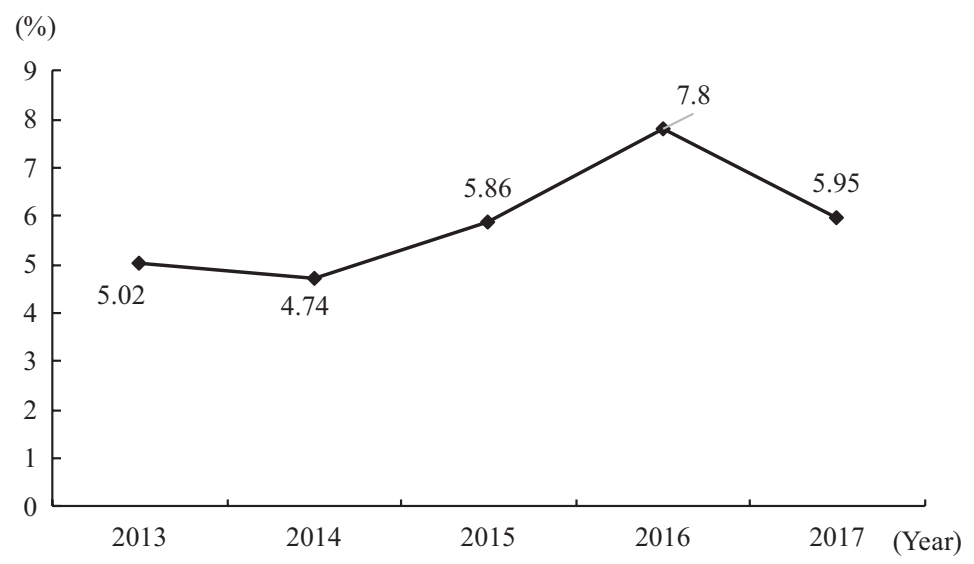

Figure 5.11 Market share of domestic films in Argentina, 2013-2017.

Summer Vacation, Jurassic World: Fallen Kingdom, Bohemian Rhapsody, Jumanji: Welcome to the Jungle, El Angel, Fifty Shades Freed, and The Nun. They are mostly Hollywood films.

\section{Analysis of the Brazilian film industry}

The Cinema Novo in Brazil, which began in the 1950s (the main idea is to develop local films in order to take back the Brazilian film market dominated by American films) has attracted widespread attention. Of these films, The Given Word won the Golden Palm Award at the 1962 Cannes Film Festival. However, since 1964, the film censorship system has tightened and the Cinema Novo has gradually declined. In the early 1990s, due to the economic downturn and the change of government, the Ministry of Culture and the Brazilian National Film Company were revoked, film funding was forced to stop, and film production began to sharply decline. The annual production was only two or three feature films, mostly medium-term budget ones. The market share of local films is less than 1 percent. This phenomenon attracted the notice of the public. In 1995, Brazil enacted the Audiovisual Law, which promoted the rapid development of Brazilian films through introducing a series of film industry promotion policies. Films such as Exotic Hometown and Brazil Princess were considered by academics to mark the "film renaissance" of Brazil. Since then, the market share of Brazilian domestic box office has continued to rise. The market share of local Brazilian movies in 2003 rose to 22 percent. Since the beginning of the twenty-first century, Brazilian films have been in crisis, and cinema attendance has been declining. As a result, around 2006, Brazilian industry insiders issued a call to "Save Brazilian Movies." In order to boost the film industry, the Brazilian government adopted 


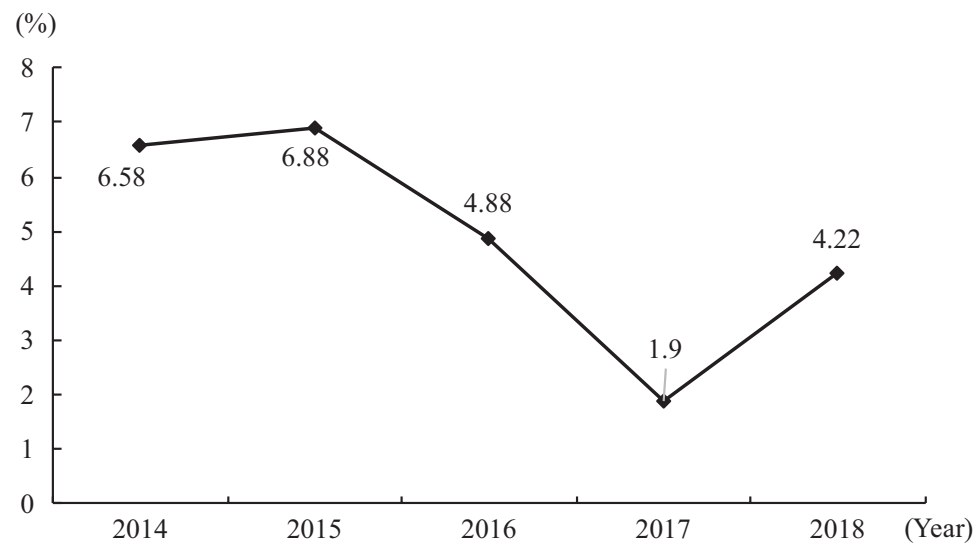

Figure 5.12 Screen growth rate in Brazil, 2014-2018.

a series of measures, including tax reduction, financial support, the establishment of the National Film Fund, the Brazilian Development Bank's preferential loans, and cooperative production. The Brazilian movie box office rose because of these measures, and successfully ranked among the top ten movie box office in the world. In order to protect Brazilian national cinema, starting in 2015, Brazil requires theaters to broadcast Brazilian movies for 28-63 days per screen, and to show 3-24 different domestic films, the number of which varies depending on the number of screens in the cinema. Inspired by a series of measures, the Brazilian film market has developed steadily. In recent years, cinema attendance has remained above 100 million.

Based on Figure 5.12, Brazil's screen growth rate has fluctuated since 2015, and declined from 2015 to 2017. However, in absolute terms, the number of screens continues to grow. In 1995, the number of screens in Brazil was only 1,033 , and the number of screens in 2018 was 3,356, the highest point in Brazilian film history.

According to the analysis, cinema attendance reached 161 million in 2018, down from 184 million in 2016, but still higher than the 149 million in 2013. Meanwhile, the growth rate has continued to decline since 2015 (Figure 5.13).

Based on the box office data, Brazil's movie box office revenue has continued to grow and the market is relatively stable in recent years. In terms of box office growth rate, except for 2015, it is basically above the positive growth level (Figure 5.14). Judging from the development trend of movie ticket prices in Brazil, the box office growth rate has increased in recent years and the highest increase appeared in 2017, with a growth rate of 46.72 percent (Figure 5.15). However, the movie ticket price in Brazil is very low. At the beginning of 2019, the price ranged from 28.61 to 31.58 real. From a global perspective, it was one of the countries with the lowest movie ticket price. 


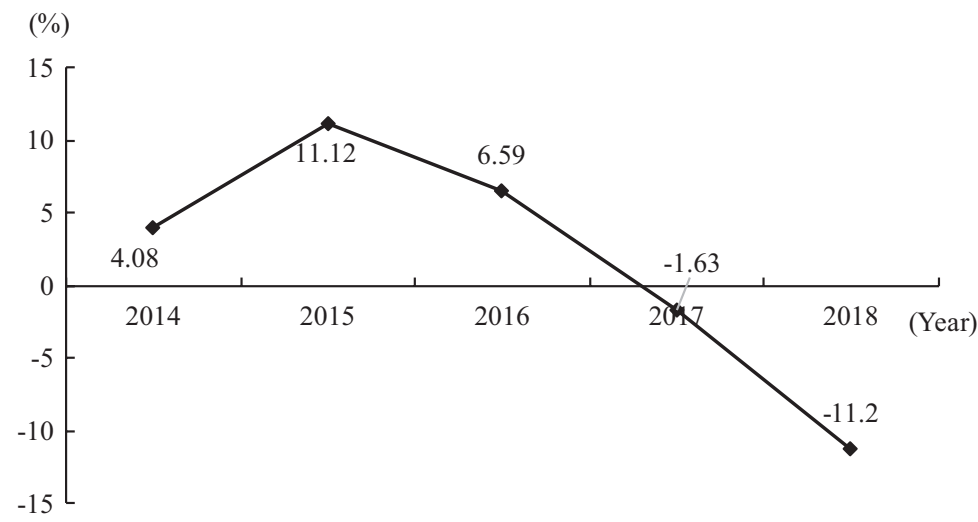

Figure 5.13 Growth rate of cinema attendance in Brazil, 2014-2018.

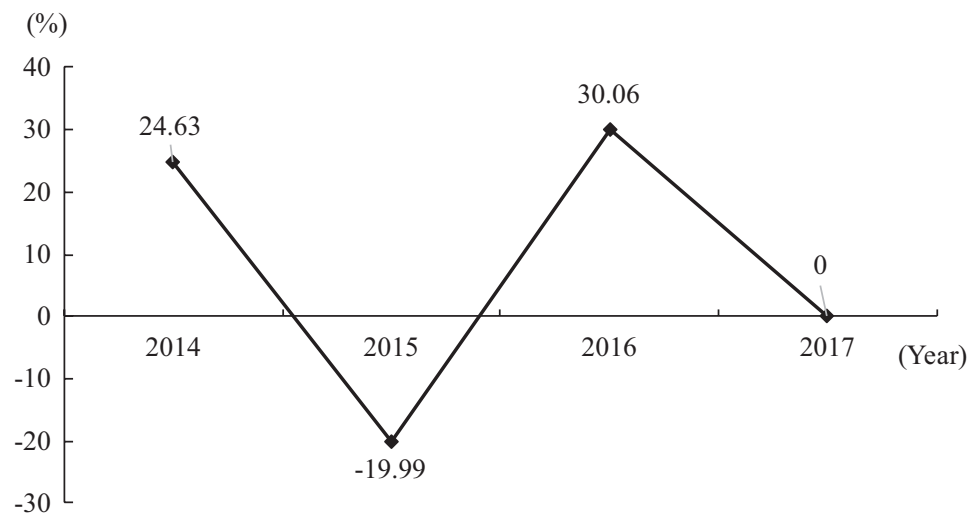

Figure 5.14 Box office growth rate in Brazil, 2014-2017.

In terms of market share, in recent years, the box office share of domestic films in Brazil has remained above 10 percent. For these films, the share in 2018 is 14.4 percent (see Figure 5.16).

In 2018, the top ten box office movies in the Brazilian film market were Avengers: Infinity War, The Incredibles 2, Black Panther, Nothing to Lose, Aquaman, Jurassic World: Fallen Kingdom, Jumanji: Welcome to the Jungle, The Nun, Hotel Transylvania 3: Summer Vacation, and Venom. Apart from Nothing to Lose, these are all Hollywood movies. However, the Brazilianproduced film Nothing to Lose is a box-office smash, which has driven the development of native films. The statistics show that in 2018, the moviegoers for domestic movies reached 23.25 million. 


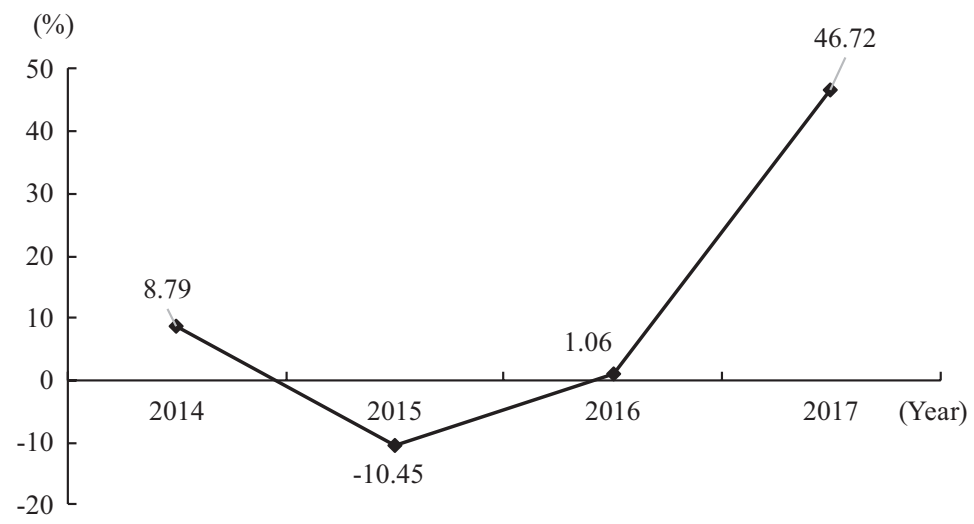

Figure 5.15 Growth rate of movie ticket price in Brazil, 2014-2017.

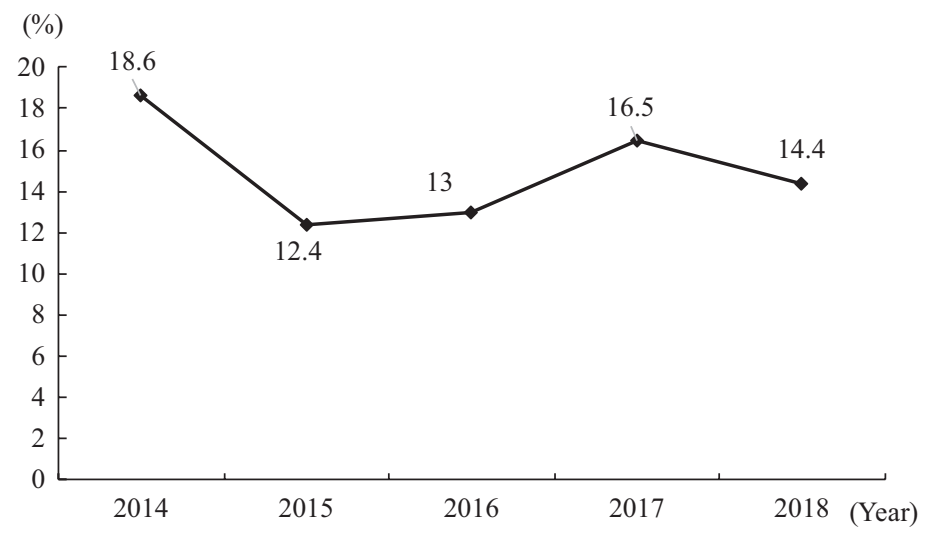

Figure 5.16 Market share of domestic movies in Brazil, 2014-2018.

\section{Analysis of the Colombian film industry}

The Republic of Colombia has a population of 48.653 million, its per capita GDP reached US\$6,302 and the human development index was around 0.7 in 2017, making it one of the countries with the biggest growth potential. In 2003, the Colombian Film Law regulated the national film strategy, providing a film development fund, tax incentives, and demanding screen quotas. In 2013, in order to promote the overseas distribution of domestic movies, Colombia decided to exempt exported films from VAT. In the past 10 years, Colombia's economic trend has been relatively stable, and the film 


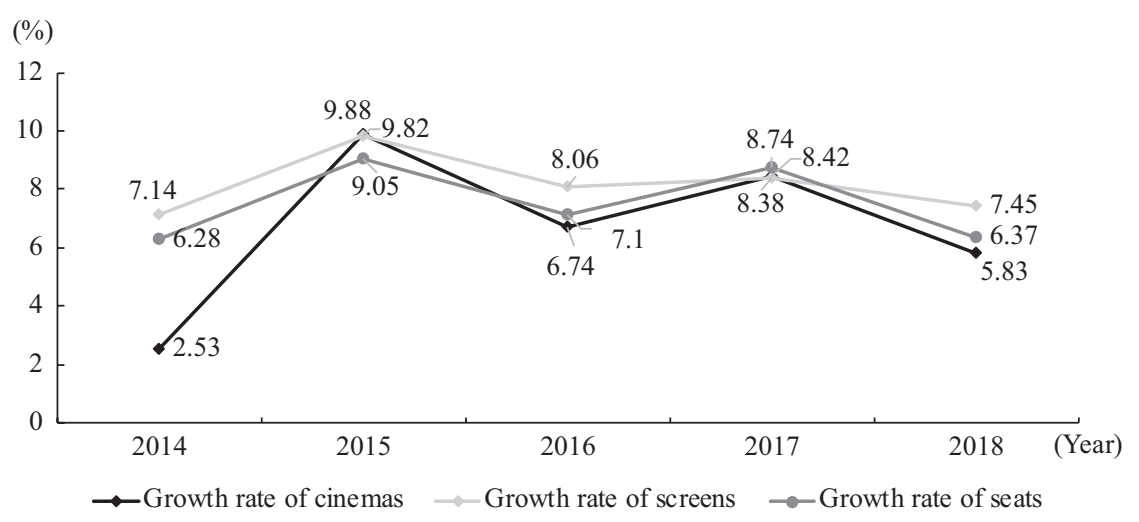

Figure 5.17 Rate of change in film infrastructure in Colombia, 2014-2018.

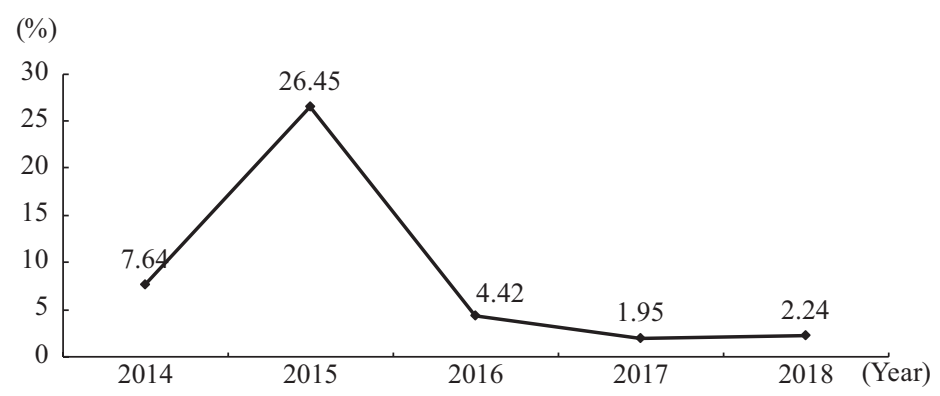

Figure 5.18 Growth rate of cinema attendance in Colombia, 2014-2018.

industry has made great progress. The gross box office has increased from US\$290 million in 2011 to US\$550 million in 2018. Colombia's film infrastructure has maintained steady and sustained growth. In 2011, there were only 135 cinemas in Colombia, increasing to 218 by 2018. There were 627 screening rooms in 2011 and 1,140 in 2018. The number of seats in theaters was 115,258 in 2011 and increased to 199,942 in 2018. Figure 5.17 shows the rate of change in Columbia film infrastructure from 2014 to 2018.

Since 2015, the growth rate of cinema attendance has been following a downward trend, but it tends to be stable and has maintained a level of stability in recent years (Figure 5.18). The data from 2016 to 2018 are basically stable with a cinema attendance of more than 60 million people. By comparison, before 2012, cinema attendance was less than 40 million. 


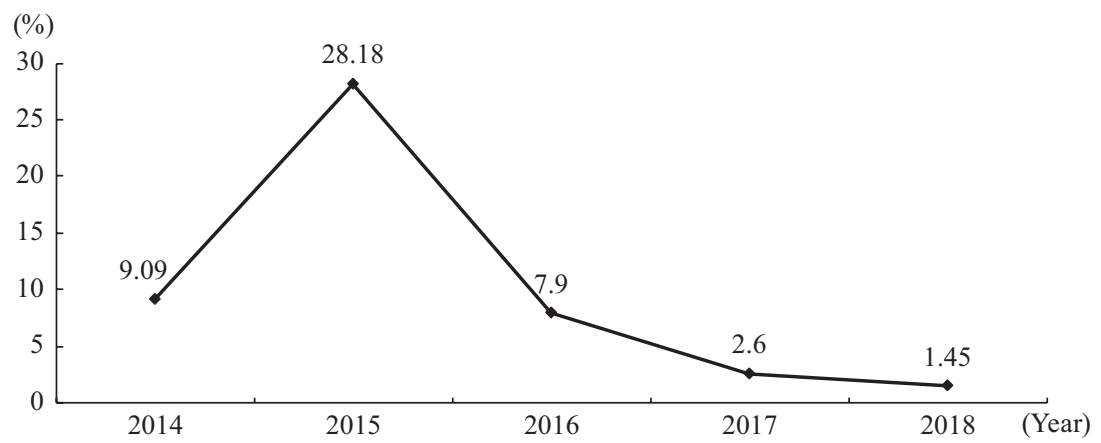

Figure 5.19 Colombia's box office growth rate, 2014-2018.

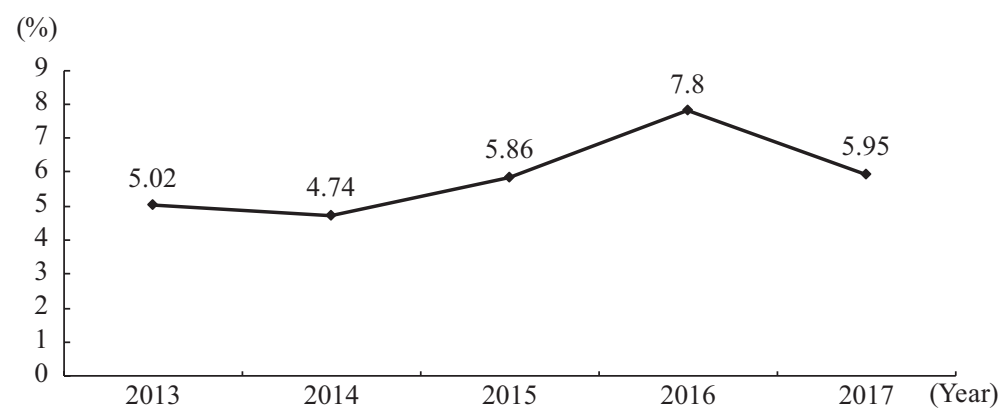

Figure 5.20 Market share of domestic films in Colombia, 2013-2017.

The growth rate of the movie box office is basically in line with the growth rate of the viewers (Figure 5.19). This is not to say that the film industry is declining but shows the maturity of the market. From 2011 to 2014, the box office grossed less than US\$300 million; in 2015, it jumped to US\$400 million; in 2016, 2017 and 2018, the revenue remained above US\$500 million.

Like many other market economies, due to the open policy in the film industry and the lack of effective protection of the local film market, Colombia's domestic film market share has remained at around 5 percent in recent years (Figure 5.20).

According to the data from 2018, the top ten movie box office winners are Avengers: Infinity War, The Incredibles 2, Aquaman, Jurassic World: Fallen Kingdom, Black Panther, The Nun, Hotel Transylvania 3: Summer Vacation, Venom, Deadpool 2 and Bohemian Rhapsody. 


\section{Conclusion}

Three countries in Latin America entered the top 20 box office of the world. The scale of the film industry in Latin America is matched by its economic development. In recent years, the film market has been relatively mature and stable.

Judging from the situation of the four major countries in Latin America, the films of Mexico, Brazil and Argentina are more commercially and culturally influential, and have won many international awards. These countries have adopted a series of policies, such as film tax reduction, financial subsidies, and the establishment of a film fund to promote the development of the film industry. The results have been good, and the film industry has continued to develop steadily. In recent years, the box office and the numbers of cinema attendance in these countries have fluctuated, but also grown steadily overall, and the film industries in these four countries have matured after experiencing a few ups and downs. Although these national cinemas in Latin America have achieved significant development, a shift of focus to arthouse films has caused the development of commercial films to lag behind relatively. Therefore, Hollywood movies have taken over the box office of these countries. 